С.І. Кіркілевський ${ }^{1}$ Ю.В. Думанський ${ }^{2}$ О.В. Лук'янчук ${ }^{3}$, А.О. Машуков ${ }^{3,4}$, О.М. Сулаєва А.Г. Лурін ${ }^{3}$, О.І. Ткаченко ${ }^{4}$, О.М. Згура ${ }^{4}$, О.А. Біленко ${ }^{3,4}$, В.С. Максимовський ${ }^{4}$ Д.В. Раціборський ${ }^{3}$

\title{
Феномен Конрада Уоддінгтона в розробці клінічно значущої молекулярної класифікації раку шлунка
}

\author{
${ }^{1}$ Онкологічна клініка «Target», Київ \\ ${ }^{2}$ Інститут експериментальної патологї̈, онкології і радіобіологї̈ ім. Р.С. Кавецького Національної академї̈ наук Украӥни, Київ \\ ${ }^{3}$ КНП «Одеський обласний онкологічний диспансер» Одеської обласної ради \\ ${ }^{4}$ Одеський національний медичний університет \\ ${ }^{5}$ Медична лабораторія CSD, Київ \\ Одержано 27.06.2020 \\ Прийнято до друку 25.08.2020 \\ DOI: $10.32471 /$ clinicaloncology.2663-466X.43-3.27712
}

\begin{abstract}
Мета дослідження. Вивчити вплив гістологічного і молекулярного фенотипу пухлин шлунка на виживаність хворих, пролікованих за стандартними протоколами. Об'єкт і методи дослідження. У цій роботі представлено результати клінічного дослідження, проведеного на базі науково-дослідного відділення пухлин органів грудної порожнини Національного інституту раку та абдомінального онкохірургічного відділення Комунального некомерційного підприємства «Одеський обласний онкологічний диспансер" Одеської обласної ради за участю 221 хворого, прооперованого з приводу раку шлунка (РШ) у період 2007-2013 рр. Середній вік становив 60,88 10,5 року, чоловіків було 180, жінок - 41. Усього виконано 143 гастректомії і 78 дистальних субтотальних резекцій. Результати. Усіх хворих, включених у дослідження, було радикально прооперовано. Вилучені під час операції пухлини досліджувалися з використанням гістологічного, імуногістохімічного методів та генетичних тестів. 3 точки зору хірурга, онколога і клініциста відслідковані отримані результати щодо наявності/відсутності клінічних паралелей і математичних кореляцій між маркерами. Зроблено висновок про ефективність поєднання деяких комбінацій імуногістохімічних маркерів для відокремлення груп хворих з різною біологією РШ. Проаналізовано виживаність груп хворих на основі аналізу молекулярних маркерів VEGFR, p53, Her2, Ki-67 і рутинних гістологічних маркерів (стадія, ступінь диференціювання та ін.). У якості арбітра ефективності нової класифікації виступає аналіз виживаності хворих на РШ. Висновки. Виконання більш розширених операцій, у тому числі D2-лімфодисекцій, було більш ефективним при мікросателітно-нестабільному і Епштейн - Барр вірус-асоційованому РШ.
\end{abstract}

Ключові слова: рак шлунка; онкобілки; імуногістохімічне дослідження; нова класифікація.

\section{ВстУП}

Загальновідомим є факт так званої дисоціації між даними впровадження в клінічну практику розширених лімфатичних дисекцій між умовними Сходом та Заходом. У той час як в Японії лімфатичні дисекції при раку шлунка (РШ) стали стандартом оперативного лікування, починаючи з 1980 -х років, у $\mathrm{E}_{\mathrm{B}}$ ропі і Північній Америці протягом 20 років тривали суперечки щодо необхідності їх виконання. Наприклад, у німецькі національні хірургічні гайдлайни D2-лімфодисекції увійшли лише в 2010 р. Будучи мимовільними спостерігачами, і в чомусь учасниками цієї суперечки, наш колектив задався простим питанням: чи не є різні дані, одержувані різними групами авторів, лише варіаціями різної пухлинної біології на Сході та на Заході. Наприклад, відоме британське дослідження MAGIC, що стало класичним та навіть енциклопедичним, досі критикують за те, що 40\% хворим на РШ, включеним до нього, взагалі не виконувалася D2-лімфодисекція. Чи можна пояснити настільки добре відомий факт різним співвідношенням молекулярно-генетичних, а отже, і біологічно різних, груп так званого різного РШ у досліджуваних популяціях?

Пацієнтів досліджували стандартно. У післяопераційний період було виконано як гістологічне, так і імуногістохімічне дослідження видалених пухлин. Незважаючи на велику кількість отриманої при цьому інформації, що включає, як правило, експресію генів (VEGFR, TP53, Her2) і їх білкових продуктів, це не було самоціллю. Нашою метою став пошук методів систематизації і будь-якого узагальнення отриманої інформації, що в кінцевому підсумку, як це буде зазначено нижче, втілиться в розробці експериментальної моделі класифікації РШ. У якомусь сенсі, з одного боку, нас надихали приклади подібної класифікації для онкопатології іншої локалізації. Наприклад, для раку молочної залози такі моделі як IHC4 (4 маркери) і РАМ50 (47 маркерів) дотепер є основою молекулярної картини пухлинної біології.

Дослідження всіх 22000 генів пухлини, тобто повногеномне секвенування, не дає інформації про поведінку пухлини і не робить їі біологію настільки зрозумілою, наскільки всі чекали від цих методик. C. Caldas [11] у Кембриджському університеті (University of Cambridge) за допомогою технології секвенування наступного покоління (next generation sequencing - NGS) досліджував 2500 пацієнтів з пухлиною молочної залози з метою виявлення більшої кількості молекулярних підтипів даної онкопатології, а також з метою більш глибокого розуміння біології цього виду раку. Секвенування останнього покоління - дуже копіткий і затратний метод дослідження пухлинного генотипу. При цьому групі C. Caldas вдалося сформувати 10 кластерів молекулярно-генетичних ознак, які дали змогу створити 10 груп пацієнтів з різною виживаністю (рис. 1).

C. Caldas чітко відокремив певну кількість кластерів при раку молочної залози. Той нечастий випадок, коли було проведено саме генетичне дослідження, а не дослідження «відзвуків роботи геному» - кембриджська група використовувала NGS. Створена при цьому нова генетична класифікація раку молочної залози поки що не змогла в гострій конкурентній боротьбі відтіснити «старі добрі» IHC4 і РАМ50. Так звані групи з незалежною виживаністю, що відрізняються одна від одної один з критеріїв того, що виявлено окрему класифікацію [11].

Фундаментальна цінність роботи була просто величезною, враховуючи обсяг і глибину проаналізованого матеріалу. Однак клінічна значимість настільки докладної і генетично глибокої класифікації, незважаючи на витрачені колосальні зусилля, на сьогодні значно поступається більш простим моделям. Не кажучи вже про складнощі використання настільки гро- 

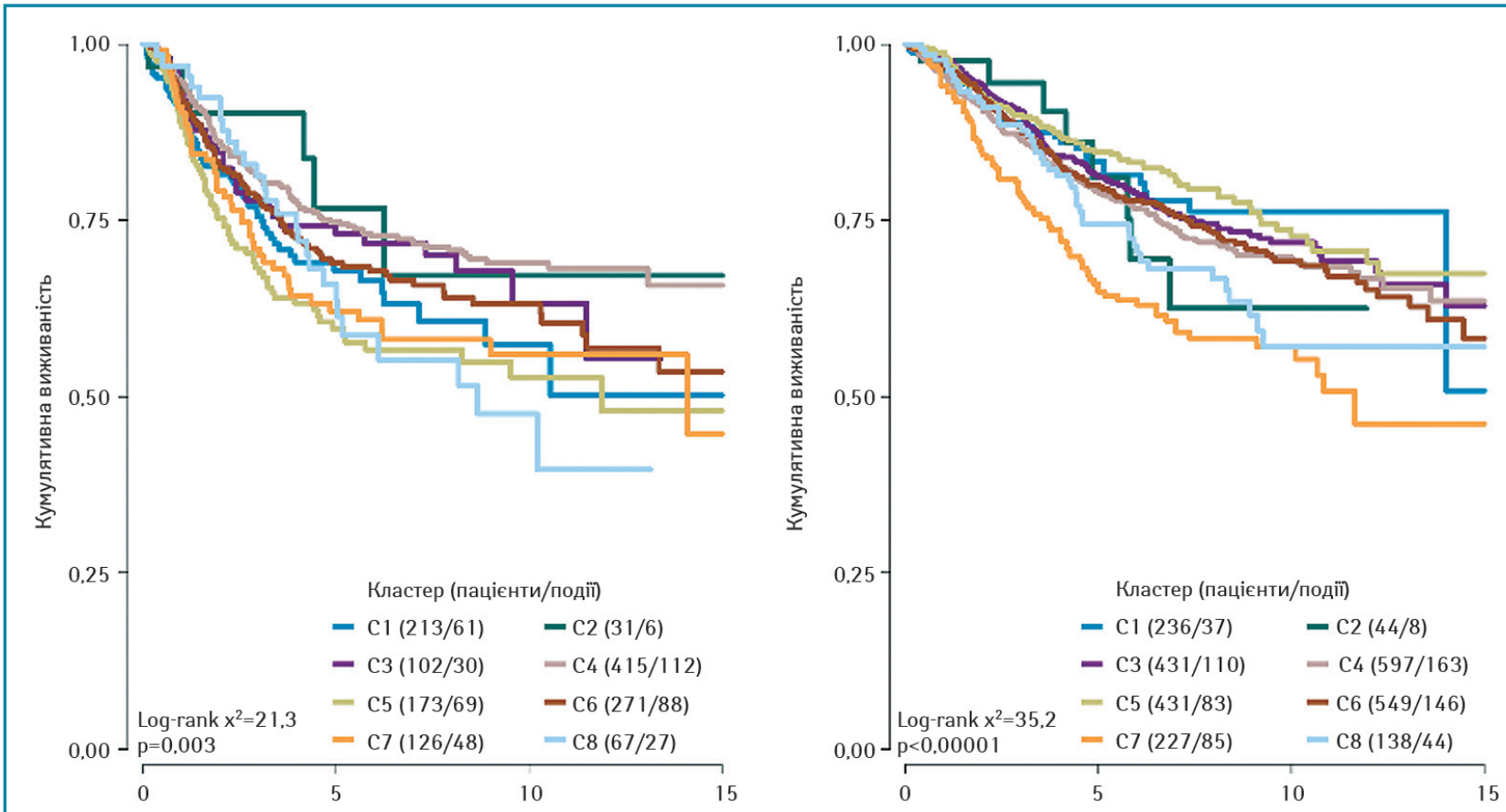

Рис. 1. Виживаність пацієнтів при раку молочної залози, досліджена C. Caldas в Кембриджському університеті за допомогою технології NGS [11]

міздкого інструменту в рутинній клінічній практиці. У чому може бути причина такого результату?

Можна сказати, що незважаючи на сучасні успіхи протеоміки та біоінформатики, саме здатність опису поведінки пухлини з точки зору «рутинного клініциста» і визначає значимість класифікації, як і актуальність її застосування в подальшому. I, здається, погляд у філософію тільки додає запитань. Саме в цьому полягає актуальність нашого прагнення осягнути всю картину в цілому. На сьогодні є кілька варіантів молекулярних класифікацій РШ, що базуються на результатах аналізу геноміки, транскриптоміки та протеоміки карцином шлунка $[5,9]$. Проте, не зважаючи на більш глибоке розуміння молекулярних основ розвитку РШ, дані класифікації не стали основою персоналізованого менеджменту пацієнтів з різними варіантами карцином шлунка.

Відомим є той факт, що до $80 \%$ всіх продуктів експресії людського, у тому числі пухлинного геному - не більш ніж, так би мовити, реліктовий «білий шум», який не має нічого спільного ні з пухлинним фенотипом, ні з біологією пухлини. Однак, чим простіше бувають обумовлені мікрофенотипові маркери (VEGFR, p53, Her2, Ki-67), чим вагомішим є їх вплив на такі елементи, як клітинний цикл, дозрівання і проліферація клітин, ангіогенез, тим, як правило, древніші ці механізми роботи клітинного мікросвіту. Тим вони стійкіші й потужнішим $€$ їх вплив на біологію і перебіг пухлинного процесу.

Подібна концепція опису значущих з точки зору пухлинної біології мутаційних процесів відома досить давно. Уперше iii запропонував на початку 1930-х років К. Уоддінгтон [12], англійський генетик, палеонтолог, біолог і філософ. Він порівнював розвиток організму з плином річки, яка від самого свого витоку до іiі гирла тече в певному руслі. Під термінами «епігенетичний ландшафт» і «каналізування» (звичайний переклад його терміна в нашій літературі як «автономність» не відображає суті гіпотези) К. Уоддінгтон розумів обмеженість кількості траєкторій руху річки, незважаючи на всю потужність і різноманіття зовнішніх факторів, що впливають на ії плин. Металева кулька на верхівці пагорба, за образним порівнянням англійського біолога, вибирає для себе всього кілька траєкторій руху, що визначаються ландшафтом або ж географією цього пагорба (рис. 2).
К. Уоддінгтон запропонував концепцію обмеженості кількості «каналізацій» всієї активності генів, незалежно від величезного розмаїття постійних мутацій і «білого шуму», згенерованого геномом і транскриптором клітини [12].

Так, незалежно від кількості мутаційного «білого шуму», $€$ всього кілька всім добре відомих фенотипів, у які виллється вся бурхлива активність і потужність генетичних механізмів. Або, якщо сказати те саме, але по-іншому, якою б великою не була потужність генетичного океану, що реве прямо під нашими ногами, епігенетичний ландшафт завжди залишається більшменш непорушним. Це і $є$ так званий феномен К. Уоддінгтона.

\section{МЕТА ДОСЛІДЖЕННЯ}

Метою дослідження $\mathbf{\epsilon}$ вивчення впливу клітинного фенотипу пухлин шлунка на виживаність хворих, прооперованих радикальним методом.

\section{ОБ 'ЄКТ І МЕТОДИ ДОСЛІДЖЕННЯ}

Усього в дослідження, проведене на базі абдомінального онкохірургічного відділення Комунальне некомерційне підприємство «Одеський обласний онкологічний диспансер»

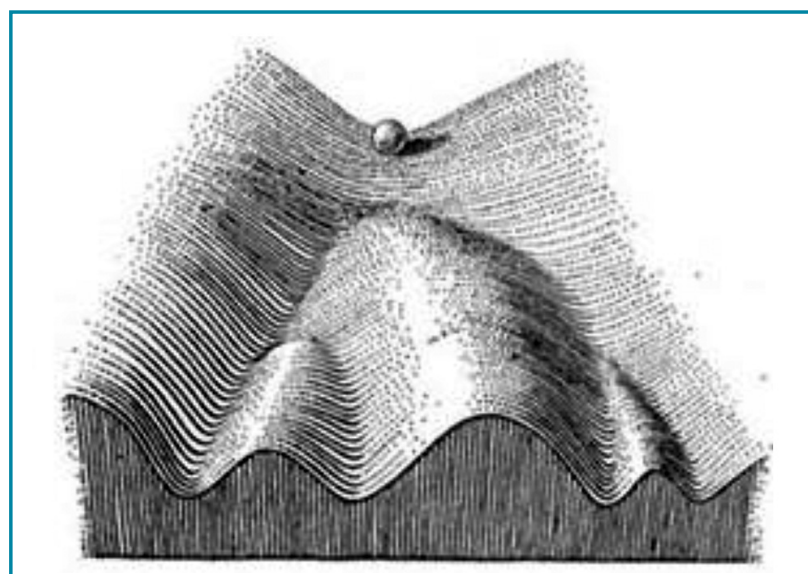

Рис. 2. Епігенетичний ландшафт, описаний К. Уоддінгтоном (1957) [12] 
Одеської обласної ради, включено 221 хворого, оперованих з приводу РШ у період 2007-2013 pр. Середній вік пацієнтів становив $60,88 \pm 10,5$ року, чоловіків було 180 , жінок -41 . Усього виконано 143 гастректомії (ГЕ) і 78 дистальних субтотальних резекцій (ДСРШ). Дизайн дослідження полягав у формуванні 4 груп хворих на РШ, яким були виконані різні комбінації розширених і комбінованих оперативних втручань: поєднання D2- і мультивісцеральної резекції (МВР) - 26 хворих, тільки D2 без МВР - 36 хворих, поєднання D1 і МBP 74 хворих, тільки D1 без МВР - 85 хворих. Дослідження було одноцентровим, ретроспективним.

Для оцінки ефективності методу лікування використовували 3 критерії: середню тривалість життя в групі; криві виживаності, що вказували на відмінності порівняно з базовою групою з $\mathrm{p}<0,05$; а також, у деяких випадках, порівняння площ під кривими виживаності, що було більш ефективним, ніж оцінка середньої тривалості життя, оскільки давало інформацію не тільки про тривалість життя хворих, але й про кількість пацієнтів, які прожили такий термін.

Як уже було зазначено, досліджували на першому етапі роботи найбільш доступні й вивчені на той час білкові продукти, експресовані на мембранах клітин РШ. Одним з них був протеїн з молекулярною масою 53 кілодальтон - p53 (клітинний пухлинний антиген р53, пухлинний супресор р53, фосфопротеїни р53, антиген NY-CO-13 - інші його назви), продукт експресії гена TP53. Протеїн р53 є одним з найвідоміших і найбільш досліджуваних онкосупресорів. Він є контролером клітинного циклу, регулює апоптоз та транскрипцію, бере участь у репарації ДНК тощо. Ген ТP53 із залученням різних механізмів (у тому числі, наприклад, альтернативного сплайсингу) кодує 12 ізоформ цього білка. Крім ізоформ р53, є ще і його посттрансляційні модифікації і так звані протеоформи. Усе це розмаїття пояснює надзвичайну багатофункціональність даного білка. Означені вище механізми є досить давніми і формують ті самі «канали» або «креоди» фенотипічної реалізації цілісної активності геному, описані К. Уоддінгтоном.

Як зазначено, порівняння кривих виживаності радикально прооперованих хворих на РШ з різним поєднанням імуногістохімічних (IГХ) маркерів дало можливість виокремити безліч нових груп хворих з різною тривалістю життя. При цьому, коли використовувалося порівняння за 1 маркером, наприклад р53, криві виживаності зливалися так, що навіть не було потрібно рахувати критерій Стьюдента (Фішера, Вілкоксона та ін.), щоб зрозуміти, що це одна експериментальна група. Пошук груп, що відрізняються одна від одної, - одна з цілей будь-якого експерименту. Аксіомою було наступне твердження: «Одна група має таку ж саму тривалість життя».

Тобто, є правильним і зворотне логічне твердження: якщо 2 (3, 4, 5 і т.д.) групи не відрізнялися, то це не 2 групи, a 1. Це твердження цілком синонімічне концепції перевірки гіпотези обчислень: $\mathrm{H}_{\mathrm{o}}$ - якщо a i b не відрізняються $(\mathrm{p}>0,05)$ i $\mathrm{H}_{1}-\mathrm{a}$ i b відрізняються одне від одного $(\mathrm{p}<0,05)$. Якщо позначити існування групи а, незалежної від групи $b$, а виживаність літерою $\mathrm{S}$ (survival), то $\mathrm{a}=\mathrm{S}_{1}, \mathrm{~b}=\mathrm{S}_{2}$. Тобто, це будуть дві різні криві і дві різні виживаності. Просто тому, що гіпотеза $\mathrm{H}_{1}$ для цих двох груп правильна $(\mathrm{p}<0,05)$, і вони відрізняються одна від одної математично. Загальна концепція могла б мати в такому разі наступний вигляд: «Будь-яка нова онкологічна класифікація може бути такою, якщо вона створює групи хворих з незалежною, відмінною від інших виживаністю».

Вищенаведені твердження були доведені під час побудови кривих виживаності і порівняння їх між собою. Для всіх розрахунків існують спеціалізовані Exel-файли (текстовий редактор Microsoft Exel 2007), що описують порядок обчислень у процесі накопичення фактичного матеріалу.

Графік, що показує використання впливу тільки 1 маркера p53 на виживаність, наведено на рис. 3.

На рис. 3 візуально видно, що це різновид гіпотези $\mathrm{H}_{\mathrm{o}} \mathrm{ip}>0,05$. На графіках нижче продемонстровано, що чим більше вико- ристано поєднань діагностичних ІГХ маркерів, тим чіткішими $\epsilon$ контури класифікації. Розподіл хворих на групи залежно від комбінації різних IГХ-маркерів впливав на визначення тривалості життя пацієнтів після ДСРШ і ГЕ, МВР у поєднанні з D2 обсягом дисекції. Формули описують математично так звані тренди наведених на графіку кривих. Загальна 5-річна виживаність групи p $53+$ становила 53\%, групи р53- хворих на РШ - 46\%.

Водночас при збільшенні кількості застосованих маркерів вплив хірургічних методик на виживаність виявляється все виразнішим. 3 накопиченням фактичного матеріалу і руху в бік збільшення кількості маркерів, відокремлювалися 4 групи їх поєднань, які найбільше вплинули на визначення прогнозу оперативного лікування РШ.

Оскільки кінцевою метою було формування груп незалежної виживаності, то найкращі результати були отримані в групах поєднання таких маркерів, як, наприклад, Her2/neu+, p53+. Це було першим кроком до складання мозаїки молекулярних підтипів РШ, які мають найвищий потенціал створення груп хворих з різною виживаністю, тобто статистично незалежних об'єктів.

Можна, звичайно, спробувати скористатися концептуально іншою методикою обчислення отриманих результатів - вимір площі під кривою. Так, наприклад, у цій схемі найбільша площа під кривою, а значить кумулятивно довша тривалість життя, виявлялася в групі хворих з поєднанням комбінації ІГХ маркерів «Her2+, p53+ та MBP».

На рис. 4 наведена виживаність хворих на РШ залежно від позитивної експресії Her2 і р53 та виду оперативного втручання. Дослідження дивергенції кривих виживаності під впливом поступового збільшення кількості маркерів у поєднанні. На цьому графіку розпочинається «велика» дивергенція кривих виживаності, яка досягає свого апогею в поєднаннях маркерів нової класифікації. Загальна 5-річна виживаність групи МВР становила 27\%, групи D2 хворих на РШ $-17 \%$, $\mathrm{D} 2+\mathrm{MBP}-0 \%$ (табл. 1).

У табл. 1 представлено відсоткове значення показника виживаності. Площа під кривою виживаності відображає від-

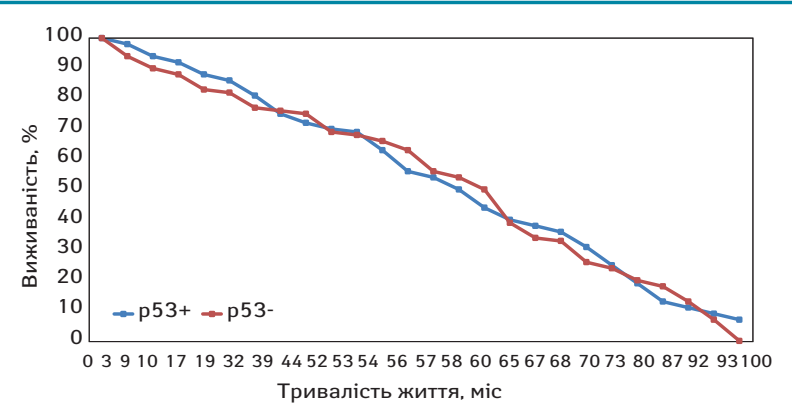

Рис. 3. Виживаність хворих на РШ з різною експресією онкобілка р53

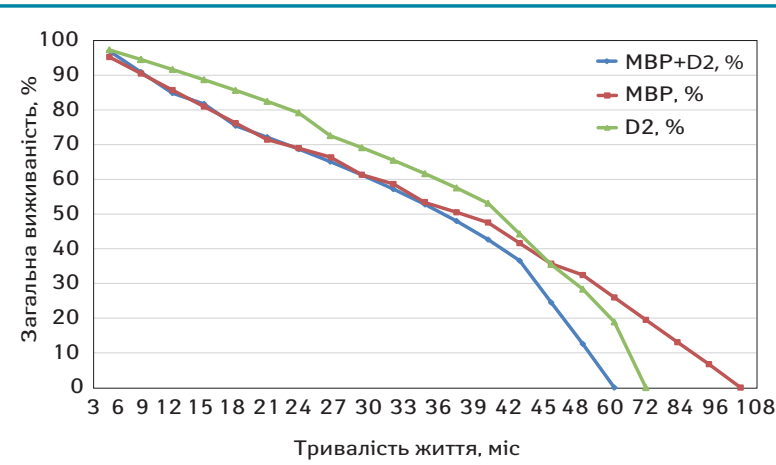

Рис. 4. Дослідження дивергенції кривих виживаності під впливом поступового збільшення кількості маркерів у поєднанні 
Таблиця 1. Розподіл тривалості життя хворих на РШ залежно від виду оперативного втручання

\begin{tabular}{|c|c|c|c|}
\hline Тривалість життя, міс & $\begin{array}{c}M B P+D 2, \% \\
n=8\end{array}$ & $\begin{array}{c}\text { MBP, } \% \\
n=35\end{array}$ & $\begin{array}{c}\text { D2,\% } \\
n=5\end{array}$ \\
\hline 3 & 96,97 & 95,24 & 97,3 \\
\hline 6 & 90,91 & 90,48 & 94,52 \\
\hline 9 & 84,85 & 85,72 & 91,65 \\
\hline 12 & 81,71 & 80,96 & 88,7 \\
\hline 15 & 75,43 & 76,2 & 85,64 \\
\hline 18 & 72,15 & 71,44 & 82,47 \\
\hline 21 & 68,71 & 68,97 & 79,17 \\
\hline 24 & 65,1 & 66,42 & 72,57 \\
\hline 27 & 61,27 & 61,31 & 69,12 \\
\hline 30 & 57,18 & 58,65 & 65,48 \\
\hline 33 & 52,78 & 53,32 & 61,63 \\
\hline 36 & 47,99 & 50,51 & 57,52 \\
\hline 39 & 42,65 & 47,54 & 53,1 \\
\hline 42 & 36,56 & 41,61 & 44,27 \\
\hline 45 & 24,51 & 35,67 & 35,45 \\
\hline 48 & 12,58 & 32,43 & 28,36 \\
\hline 60 & 0 & 25,97 & 18,91 \\
\hline 72 & & 19,51 & 0 \\
\hline 84 & & 13,08 & \\
\hline 96 & & 6,72 & \\
\hline 108 & & 0 & \\
\hline $\begin{array}{c}\text { Площа під кривою вижива- } \\
\text { ності, S, од. }\end{array}$ & 19760,73 & 26505,99 & 24878,1 \\
\hline
\end{tabular}

ношення роки/пацієнти (місяці життя помножені на загальну кількість хворих) і є більш значущим показником, ніж просто велика тривалість життя.

Поєднання Her2+ i p53+ покращувало прогноз щодо ГЕ, ДСРШ в поєднанні з D2 і погіршувало при одночасному виконанні хірургом MBP і D2. Як буде сказано нижче, комбінація ІГХ маркерів Her2+, p53+ при РШ відповідала II типу РШ генетичної класифікації: найчастіше це кишкова форма РШ, яка не має проявів неоангіогенезу. Поєднання Her2+, p53+ стало однією з небагатьох сходинок, які наблизили до розуміння 4 основних груп РШ. Для докладнішого вивчення цих поєднань та їх впливу на виживаність наводимо криві виживаності груп наступних поєднань ІГХ маркерів.

- VEGFR-, p53-, Her2+, Ki-67- i VEGFR-, p53+, Her2+, $\mathrm{Ki}-67+$;

- «потрійний негативний» РШ VEGFR-, p53-, Her2-;

- VEGFR-, p53+, Her2-, Ki-67+, MBP i VEGFR-, p53+, Her2-, Ki-67+ без MBP;

- VEGFR-, p53+, Her2-, Ki-67 + i VEGFR-, p53-, Her2+, $\mathrm{Ki}-67-$;

- VEGFR-, p53+, Her2+, Ki-67+;

- VEGFR-, p53 +, Her2-, Ki-67+ з різними поєднаннями MBP i D2;

- VEGFR-, p53+, Her2-, Ki-67+ в поєднанні з різною локалізацією пухлини в шлунка;

- VEGFR-, p53 +, Her2-, Ki-67 + i VEGFR-, p53-, Her2-, $\mathrm{Ki}-67+$;

- VEGFR-, p53+, Her2+, Ki67+ i VEGFR +, p53-, Her2-, $\mathrm{Ki} 67+$;

- VEGFR+, p53-, Her2-, Ki-67+ залежно від різного ступеня залученості мікроциркуляторного русла: $\mathrm{V}_{\mathrm{o}} \mathrm{i} \mathrm{V}_{2-3}$.

- p53-, VEGFR+, Her2+, Ki-67+; p53+, VEGFR-, Her2+; p53+, VEGFR, Her2-; p53-, VEGFR-, Her2+;

- поєднання p53-, VEGFR+, Her2+, Ki-67+; p53+, VEGFR-, Her2+; p53+, VEGFR-, Her2-; p53-, VEGFR-, Her2+ 3 MBP i D2

Усі ці порівняння дозволили виділити групи хворих на РШ з різним впливом на результати хірургічних операцій з точки зору кривих виживаності хворих (рис. 5, 6).

Розподіл хворих на РШ з експресією різних факторів було цікаво спостерігати з точки зору вираженості того чи іншого маркера в групах. Приклад:

p53-(22,89\%), VEGFR-3- (35,63\%), Ki67- (65,79\%), Her2- $(34,96 \%)$ хворих мали високий і помірний ступінь гістологічного диференціювання, від усіх ІГХ тестів; p53+ (50,48\%), VEGFR-3+ (56,43\%), Ki67+ (66,67\%), Her2 + $(37,78 \%)$ хворих мали низький ступінь або взагалі у них було відсутнє гістологічне диференціювання.

Виконання розширених і комбінованих (див. рис. 6) операцій збільшувало виживаність хворих 1-ї групи $(\mathrm{p}<0,05)$ і недостовірно - 2-ї групи. На графіку продемонстровано значне збільшення виживаності при дифузному раку 1-ї генетичної групи (див. рис. 5). Математичні формули описують можливості регресійного аналізу з метою прогнозування тривалості життя різних груп хворих.

При спробі описати кривими виживаності 1-й тип РШ (див. рис. 5) і його вплив на тривалість життя хворого після хірургічного лікування, з'ясувалося, що виконання більш розширених чи більш комбінованих обсягів резекції не сприяло поліпшенню виживаності. У перший рік трохи більшу виживаність відмічали у пацієнтів, яким було виконано більш розширені операції, у наступні 4 роки криві накладалися одна на одну; р становило явно більше 0,05 . Взагалі ж, дифузна форма, або linitis plastica, є дуже агресивним типом РШ, оскільки виявлений у ньому ген $C D H 1$ кодує білок Е-кадгерин. Останній забезпечує формування міжклітинних зв'язків на зразок «міжклітинного цементу», склеюючи клітини, не даючи пухлині завчасно метастазувати. При дефектному Е-кадгерині, його аберантній продукції гематогенне метастазування відбувається швидше і раніше. Багато хто пам'ятає «крилаті» вислови, що використовувалися колись у класичних монографіях з вивчення РШ (О.В. Мельников): «маленькі пухлини дають великі метастази». Це саме такий випадок. Як видно з графіків, довго жили лише близько $20 \%$ хворих групи I генетичного типу. Тобто, у даному випадку основна надія не на операцію і хіміотерапію, а на раннє виявлення таких хворих.

Орієнтуючись на поєднання маркерів, були виділені 4 групи хворих, перспективні з точки зору впливу на виживаність при тих чи інших видах операцій: 1) p53-, VEGFR+, Her2+,

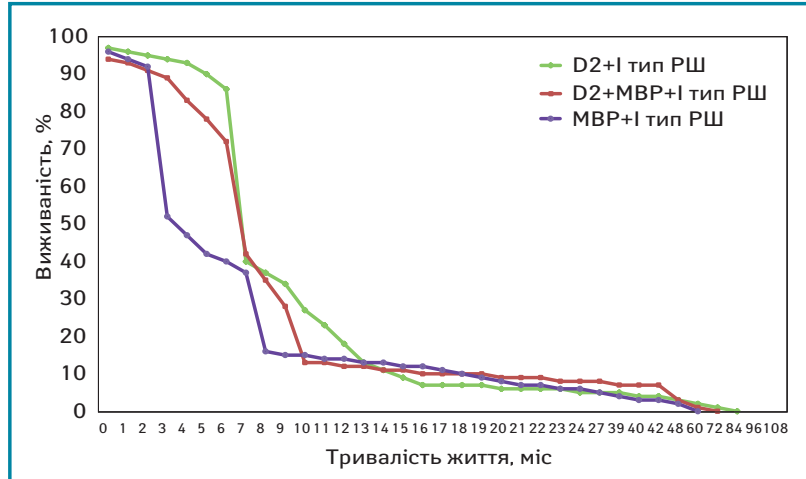

Рис. 5. Виживаність хворих на РШ 1-ї групи залежно від виду проведеної операції

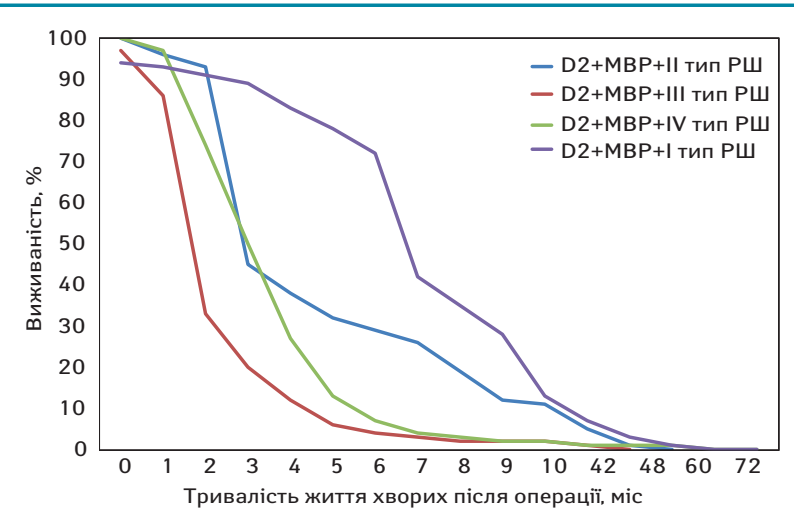

Рис. 6. Виживаність хворих на РШ 1-ї, 2-ї, 3-ї і 4-ї групи при виконанні розширених комбінованих операцій 
$\mathrm{Ki}-67+$, дифузний рак; 2) p53+, VEGFR-, Her2+, кишкова форма РШ; 3) p53+, VEGFR-, Her2-, слизопродукуюча форма, «I некардіальний рак»; 4) p53-, VEGFR-, Her2+, «II некардіальний рак» (чисельність груп представлено в табл. 2).

Групи багато в чому близькі і відповідають класифікації Атласу ракового геному (The Cancer Genome Atlas - TCGA), але також мають багато спільного з класифікацією Азіатської групи досліджень раку (Asian Cancer Research Group - ACRG), у якій наголос робиться на визначенні 53 і проявів мікросателітної нестабільності. Додатково у хворих досліджували маркери CDH1, а також MLH1, MLH3, MSH2, MSH6 (згідно з найновішими рекомендаціями Європейського товариства медичної онкології (European Society for Medical Oncology - ESMO) 2018 p. з імуноонкології слід проаналізувати 3 маркери: MLH1, MSH2, MSH6). Маркер BRCA-1 при РШ розглядався як кандидат для створення 5-ї групи. Водночас у 10 хворих, яким виконано дослідження даного маркера методом піросеквенування за допомогою полімеразної ланцюгової реакції в реальному часі, не була виявлена мутація гена $B R C A-15382$ insC, що не дозволило виділити цих пацієнтів в окрему групу дослідження. Мутацію було зафіксовано. Залишили 4 групи. Повної аналогії 3 класифікацією TCGA не було, тому що, наприклад, у жодному випадку з усіх консультованих блоків мутація гена PIKЗCA, фосфоінозітол-3-кінази, не була виявлена Е542K (c.1624 G> A), E545K (c.1633 G> A), E545Q (c.1633 G> C), H1047R (c.3140 A>G), H1047L (c.3140 A>T) та ін. (табл. 2)

Вивчення мутацій в ГТФ-азному білку-інгібіторі RhoA (продукт гена $A R H A, 3$-тя хромосома), і маркера епітеліально-мезенхімального переходу транслокації CLDN18ARHGAP26 не проводилося.

Виживаність хворих на РШ 2-ї групи залежно від виду проведеної операції наведено на рис. 7.

У групі хворих на РШ 2-го типу (див. рис. 5, табл. 2) найбільше поліпшувалася виживаність хворих при виконанні МВР операцій. Усього таких випадків було 39 з 69 хворих даної групи (див. табл. 2), що досить для підведення підсумків за даним графіком. Необхідний розмір вибірки з імовірністю $90 \%$ для даного висновку був 35 хворих, з імовірністю 95\% 40 хворих. Тобто, можна сказати так: виконання МВР збільшуе виживаність хворих II типу РШ з імовірністю 90\%. Помаранчевою стрілкою вказаний рух дивергенції кривих виживаності у разі поєднань маркерів (рис. 8).

Чисельність 1-ї (крива фіолетового кольору, див. рис. 6) і 4-і (крива зеленого кольору) генетичних груп була математично достатньою - 13 і 16 хворих при загальній кількості 35 пацієнтів (див. табл. 2) у цій категорії дослідження. Це дозволило статистично вірогідно визначити, що розширені операції були більш ефективними з точки зору впливу на виживаність у 4-й групі при порівнянні з 1-ю. Різнокольоровими стрілками вказана наявність дивергенції кривих виживаності створеної класифікації.

Найбільша виживаність була характерна для хворих 3-ї групи в поєднанні з виконанням комбінованих і мультиорганних операцій (рис. 9). Усього таких пацієнтів було 18 з 45 хворих цієї когорти (див. табл. 2). Необхідний розмір вибірки становив 16 осіб для оформлення висновків з точністю 95\%. Ця категорія пацієнтів у нашому дослідженні була близькою до так званого мікросателітно-нестабільного РШ. За даними літератури, уже близько 10 років відомо, що мікросателітно-нестабільні РШ вважаються перспективними для виконання хірургічного лікування в місцево-поширеній стадії [4]. Помаранчевою стрілкою вказаний рух дивергенції кривих виживаності при поєднанні маркерів.

Виживаність хворих на РШ, які перенесли комбіновані операції, представлено на рис. 10.

На рис. 8 зазначено, що найбільша виживаність була характерна для хворих 2-ї групи. Усього спостерігалося 40 таких осіб з 75 пацієнтів цієї когорти (див. табл. 2). Необхідний розмір вибірки для 95\% точності висновків становив 27 хворих, що було достатнім для проведення дослідження.

Отже, при поєднанні експресії онкобілка р53 нижче 10\%, наявності позитивної ІГХ реакції з маркером неоангіогенезу, індексу проліферації Кі-67 понад 20\%, а також за позитивного

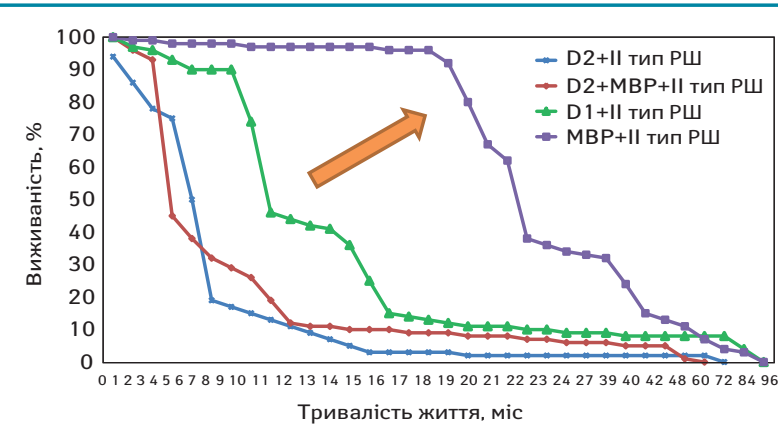

Рис. 7. Виживаність хворих на РШ 2-ї групи залежно від виду проведеної операції

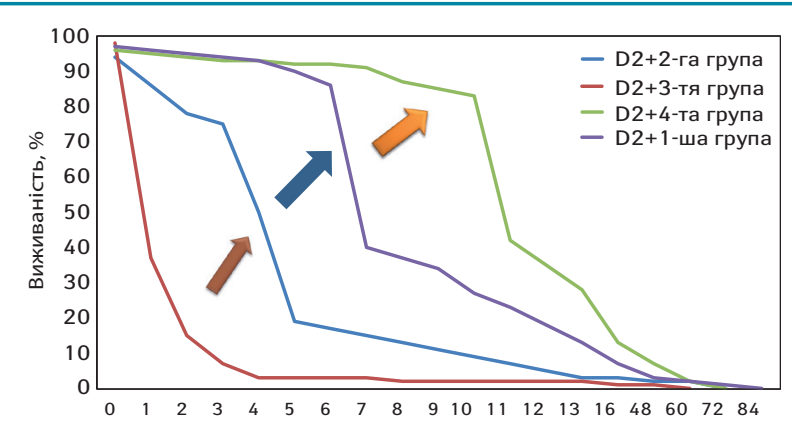

Тривалість життя хворих на РШ після радикальних втручань, міс

Рис. 8. Виживаність хворих на РШ при виконанні розширених операцій із застосуванням D2 лімфатичних дисекцій

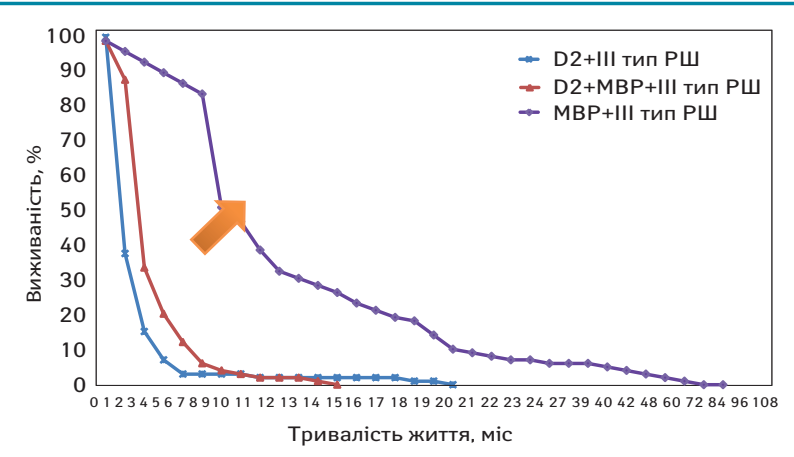

Рис. 9. Виживаність хворих на РШ 3-ї групи залежно від виду проведеної операції

Таблиця 2. Розподіл генетичних груп на групи операцій

\begin{tabular}{|c|c|c|c|c|c|}
\hline \multirow{2}{*}{ Вид виконаної операції } & \multicolumn{4}{|c|}{ Група, n (\%) } & \multirow{2}{*}{ Усього } \\
\hline & 1-ша & 2-га & 3-тя & 4-та & \\
\hline ГЕ, ДСРШ + D 2 , без МВР & $13(5,88)$ & $5(2,26)$ & $2(0,91)$ & $16(7,24)$ & $36(16,29)$ \\
\hline ГЕ, ДСРШ + $\mathrm{D}_{2}$, в поєднанні з МВР & $10(4,53)$ & $9(4,07)$ & $2(0,91)$ & $5(2,26)$ & $26(11,77)$ \\
\hline ГЕ, ДСРШ + без $\mathrm{D}_{2}$ i MBP & $24(10,86)$ & $16(7,24)$ & $23(10,41)$ & $22(9,96)$ & $85(38,46)$ \\
\hline ГЕ, ДСРШ + МВР без $D_{2}$ & $8(3,62)$ & $39(17,65)$ & $18(8,15)$ & $9(4,07)$ & $74(33,48)$ \\
\hline $\mathrm{У}_{\text {сього }}$ & $55(24,89)$ & $69(31,22)$ & $45(20,36)$ & $52(23,53)$ & $221(100,0)$ \\
\hline
\end{tabular}




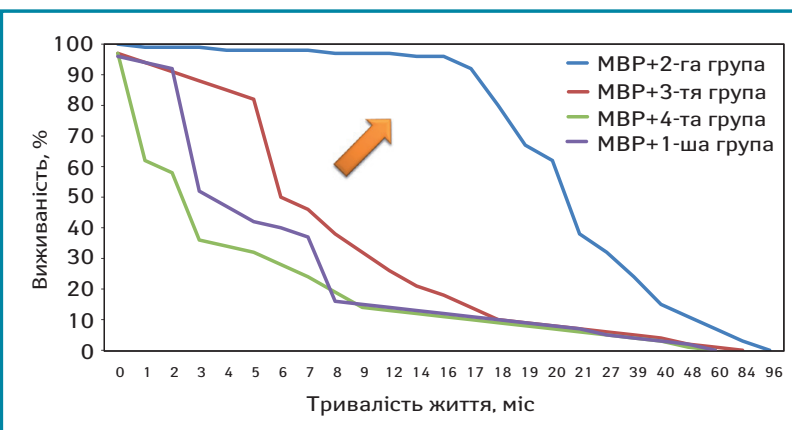

Рис. 10. Виживаність хворих на РШ, які перенесли комбіновані операції

маркера CDH1 і дифузного гістологічного типу РШ констатували РШ І генетичного типу. При експресії р53 понад 10\%, відсутності проявів неоангіогенезу, Her2+ IГХ-реакції і локалізації пухлини в кардіальному відділі визначали РШ ІІ типу. При позитивному р53, негативному рівні неоангіогенезу, негативній експресії Her2 і «некардіальній» локалізації пухлини ідентифікували РШ ІІІ типу. Разом з тим при позитивній експресії Her2, відсутності показників неоангіогенезу і експресії p53 нижче $10 \%$ у поєднанні з «некардіальною» локалізацією пухлини визначали PШ IV типу. Помаранчевою стрілою вказано напрямок дивергенції кривих виживаності створених нами груп класифікації.

Простежено паралелі між розробленою класифікацією i 2 іншими генетичними класифікаціями, актуальними для РШ.

Отже, ознаки РШ І типу становили: поєднання низької, нижче $10 \%$, експресії онкобілка р53, наявність хоча б слабкої експресії VEGFR-C, високий, понад 20\%, проліферативний індекс пухлини, високий місцево-деструюючий тип мікроінфільтрації інтерферону- $\gamma$, низький, або ж відсутній ступінь диференціювання пухлини, а також всі гістологічні варіанти, що відповідають «дифузному» типу РШ. Усього з 221 хворого в групу РШ І типу віднесено 43 пацієнти, тобто 19,46\%. У цій дослідженій групі також брали до уваги мутації в гені $C D H 1$.

РШ ІІ типу, або Her2+ РШ (хромосомно-нестабільний варіант), включав 70 хворих, що становило 31,67\%. Ці пухлини характеризувалися не тільки наявністю вираженої експресії crbB2 (Her2, CD340), але і більш ніж 10\% рівнем онкобілка p53 і повною відсутністю IГХ-реакції VEGFR-C. Позитивним результатом вивчення рівня маркера Her2 при РШ вважали наявність хоча б двох «плюсів» забарвлення на СВ11, СВЕ1, 5А2 або 10А7 [10]. Підказкою в умовах обмеженості кількості виконаних молекулярних тестів для визначення даного виду пухлини був так званий кишковий тип РШ (за Lauren, 1965) [1-3]. Також цей варіант РШ називається проксимальним, що полегшувало його ідентифікацію.

Всього чисельність IV групи (рис. 11, табл. 2) становила 52 радикально прооперованих хворих. Кількість пацієнтів з виконаною D2-дисекцією без МВР, що на графіку позначено зеленим кольором, становила 16 хворих. 3 85\% ймовірністю чисельність вибірки, достатньої для будь-яких висновків, мала б бути 26 осіб ( $34-3$ 95\%; 42 - 3 99,7\%). Тобто 16 хворих було недостатньо для отримання вірогідних результатів. Однак продемонстроване значне відхилення у графіку кривої виживаності в цій підгрупі підтвердило подібну ефективність виконання D2-дисекції в окремих регіонах світу, наприклад у Японії. Так, у дослідженні Канеди відсоток так званого некардіального раку становив $31 \%$. Помаранчевою стрілкою візуалізовано напрямок дивергентного руху кривих виживаності при створенні новітніх генетичних груп.

РШ III типу характеризувався негативною експресією онкобілка crbB2 (Her2 або CD340), позитивним p53, відсутністю проявів лімфангіонеогенезу і його білка-індикатора VEGFR-C, «поганою» гістологією, з наявністю периневральної і периваскулярної інвазії, низько- і недиференційованих форм РШ, а також високого місцево-деструюючого типу мікроінфільтрації інтерферону- $\gamma$. Ключовою була також ІГХ ідентифікація інактивованого гена $M L H 1$. Цей ген є одним з представників системи репарації помилок комплементарності ДНК (mismatch repair - MMR), що включає MLH1, MLH3, MSH2, MSH6, PMS та ін. Їх білкові продукти складають так звані repairosome [8], які виправляють помилки комплементарності ДНК, що виникли внаслідок її точкових мутацій. 3221 хворого, який брав участь у дослідженні, 50 пацієнтів мали мікросателітно-нестабільний РШ, що становило 22,62\%. Цю форму РШ, як і Епштейн - Барр вірус-асоційований РШ, відносять до некардіальних РШ, що полегшувало їх виявлення в досліджуваній групі. Високомікросателітнонестабільний РШ пов'язаний з гіперметилюванням [7] найбільш активних ділянок ДНК - CpG-острівців (скупчень ДНК-послідовностей з високим вмістом цитозину і гуаніну). Ще одним показником гіперметилювання промоутерів (тобто мікросателітно-нестабільного РШ) є продукція клітинами слизу [6] - так званий перснеподібноклітинний рак. Також гістологічно можна запідозрити мікросателітно-нестабільний РШ за ступенем лімфоцитарної інфільтрації тканин пухлини, що й доведено.

I, нарешті, РШ IV типу, характеризувався як відсутністю проявів лімфангіонеогенезу і експресії його білка-індикатора VEGFR-C, так і наявністю позитивної IГХ-реакції crbB2 (Her2, CD340) в поєднанні з низьким, нижче $10 \%$ рівнем експресії онкобілка р53. Дослідження наявності інактивованого гена $C D K N 2 A$, мутації PD-L2, фосфоінозитол-3-кінази не проводилося. Водночас вивчалася мутація PD-L1 у 58 хворих, що становило 26,24\%. 3 огляду на велику кількість молекулярних тестів, необхідних для ідентифікації Епштейна - Барр вірусасоційованого РШ, ця група була створена переважно методом виключення після відокремлення перших трьох. Також значно полегшувала її встановлення локалізація Епштейна - Барр вірус-асоційованого раку в шлунку (некардіальний рак).

\section{РЕЗУЛЬТАТИ ДОСЛІДЖЕННЯ}

Зроблено висновки 2 рівнів доказовості: з належною достовірністю відмінностей між вибірками (кривими виживаності); і $з$ достатньою чисельністю груп для обчислення отриманих даних. Із цієї статті логічні підсумки спостережень зроблені, якщо р було менше 0,05 , а розмір вибірки був задовільним з 95\% вірогідністю:

1) експериментально виведені 4 біологічних типи РШ, які диференційовано відповідають на застосування програми індивідуалізації хірургічного лікування. I тип має наступну комбінацію маркерів - p53-, VEGFR+, Her2 +, Ki-67+, дифузний рак; II тип - p53+, VEGFR-, Her2+, кишкова форма РШ; III тип - p53+, VEGFR-, Her2-, часто - продукція слизу, I некардіальний рак; IV тип - p53-, VEGFR-, Her2+, II некардіальний рак;

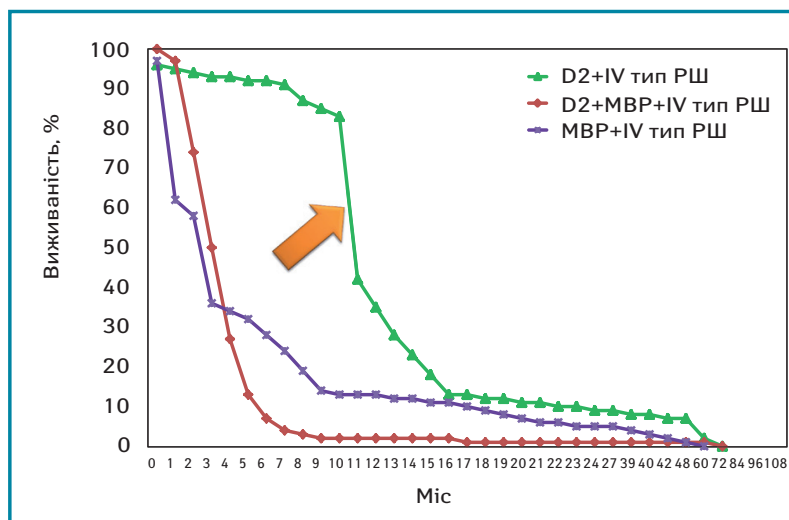

Рис. 11. Виживаність хворих на РШ 4-ї групи залежно від виду проведеної операції 
2) встановлено, що виконання розширених і комбінованих операцій збільшувало виживаність хворих на дифузний РШ І типу. Медіана виживаності цієї групи становила 7 міс. Розмір вибірки (31 хворий) був достатнім для оформлення висновків з точністю 95\%. Відмінності між кривими виживаності теж були статистично достовірними; $\mathrm{p}<0,05$;

3) при РШ II типу найбільше поліпшувалася виживаність хворих при виконанні МВР, 48 з 69 хворих II генетичного типу, що досить для підбиття підсумків. Медіана виживаності цієї групи становила 20,5 міс. Необхідний розмір вибірки зімовірністю 95\% 40 хворих. Тобто, можна констатувати: виконання МВР збільшуе виживаність хворих ІІ типу РШ з імовірністю 95\%; $<<0,05$;

4) чисельність хворих I і IV типу була різною - 55 і 52 хворих. Медіана виживаності груп становила 7 i 11 міс відповідно. D2 лімфатичні дисекції збільшували виживаність хворих I та IV типу хворих на РШ. Відмінності між кривими виживаності хворих без D2-дисекцій були статистично достовірними; $\mathrm{p}<0,05$. Існувало статистично достовірне збільшення виживаності хворих обох груп після виконання об'єму D2. Розмір вибірки був достатнім для оформлення висновків з точністю 95\%;

5) найбільша загальна виживаність була характерна для хворих III типу РШ у поєднанні з виконанням комбінованих і мультиорганних операцій. Усього до цієї групи входило 45 хворих, медіана виживаності цієї групи становила 6 міс. Разом з тим, необхідний розмір вибірки становив 16 хворих для оформлення висновків з точністю 95\%. Ця категорія хворих у нашому дослідженні була близькою до так званого мікросателітно-нестабільного раку, який є перспективним для виконання хірургічного лікування в місцево-поширеній стадії;

6) усього чисельність IV типу хворих на РШ становила 52 радикально прооперованих пацієнтів. До групи D2 без МВР входило 16 хворих, медіана виживаності цієї групи становила 11 міс. 3 85\% ймовірністю вірогідності висновків чисельність вибірки, достатньої для будь-яких висновків, тут становила 26 (34- 3 95\%; $42-3$ 99,7\%). Тобто 16 хворих було недостатньо. Однак існувало статистично достовірне збільшення виживаності, p $<0,05$, групи D2 без МВР щодо трьох інших груп. Зроблено висновок про вищу ефективність виконання D2 без МВР операцій у хворих IV типу РШ порівняно з іншими молекулярними типами цієї онкопатології;

7) виявлена тенденція до появи відмінностей у виживаності 52 хворих IV групи залежно від виду проведеної операції, особливо в підгрупі, де виконана D2-дисекція без МВР, яка налічувала 16 пацієнтів ( $>0,05)$;

8) загальна 5-річна виживаність р53+ групи становила 53\%, p53- групи хворих на РШ $46 \%$.

Поєднання факторів спостерігалося в 3 випадках. Отримані результати оформлені у вигляді висновків і максимально прості. 3 метою деталізації біологічної агресивності пухлини, визначення прогнозу перебігу захворювання та розробки персоніфікованої тактики ад'ювантного хіміотерапевтичного і імуно-клітинного лікування доцільним є визначення генетичного варіанта РШ в післяопераційний період.

\section{ВИСНОВКИ}

1. Створена нова клініко-молекулярна класифікація РШ.

2. Різні групи хворих на РШ, згідно з новою класифікацією, мають різну виживаність.

3. Вид проведеного онкологічного лікування впливає на виживаність різних генетично-молекулярних груп по-різному.

4. Виконання більш розширених операцій, у тому числі D2 лімфодисекцій, було більш ефективним при мікросателітнонестабільному і Епштейна - Барр вірус-асоційованому РШ.

Найкращу медіану виживаності в дослідженні продемонструвало поєднання виконання комбінованих і мультиорганних оперативних втручань у хворих з ІІ типом РШ (у тому числі «кишкова» гістологічна форма) - 21 міс; на 2-му місці було виконання D2 лімфодисекцій у хворих з IV типом РШ - 11,8 міс (екзофітні пухлини, часто розташовані в антральному відділі).
Підбиваючи короткі підсумки, можна сказати, що виконання більш розширених операцій, у тому числі D2 лімфодисекцій, було ефективнішим при мікросателітно-нестабільному і Епштейна - Барр вірус-асоційованому РШ. Найчастіше ці 2 форми виникають у дистальних відділах шлунка. У країнах Північної Америки переважає так звана дифузна, інфільтративна форма РШ. Водночас в Японії, Південній Кореї часто відмічають екзофітні пухлини дистальних відділів шлунка. Саме з цієї причини виконання дисекцій на Сході виявилося історично більш ефективним: дистальний екзофітний рак менш агресивний, ніж дифузний інфільтративний, у тому числі у зв'язку з іншою біологією цих пухлин, іншим біологічним співвідношенням різних видів РШ. Збільшення кількості біологічних кластерів РШ, таким чином, мало вплинуло на наше розуміння клінічних особливостей цього захворювання. Морфологічний поділ цих пухлин за Лауреном на дифузні й кишкові форми дотепер актуальний.

\section{СПИСОК ВИКОРИСТАНОЇ ЛІТЕРАТУРИ}

1. Барышев, А. Г. (2011). Отдаленные результаты лечения больных раком желудка в свете биомолекулярных особенностей опухоли. Российский биотерапевтический журнал, 2, 85-88.

2. Василенко, И. В., Гульков, Ю. К., \& Запорожченко, Н. В. (2011). Гистологическая гетерогенность рака желудка. Український морфологічний альманах, 9(1), 26-31.

3. Данилова, И. В. (2005). К вопросу о клинико-морфологических вариантах рака желудка. Архив патологии, 67(5), 32-34.

4. Имянитов, Е. Н. (2010). Спорные аспекты Her2-диагностики. Современная онкология, 3, 15-19.

5. Chivu-Economescu, M., Matei, L., Necula, L. G., Dragu, D. L., Bleotu, C., \& Diaconu, C. C. (2018). New therapeutic options opened by the molecular classification of gastric cancer. World Journal of Gastroenterology, 24(18):1942-61. doi: 10.3748/wjg.v24.i18.1942).

6. Coppedè, F., Lopomo, A., Spisni, R., \& Migliore, L. (2014). Genetic and epigenetic biomarkers for diagnosis, prognosis and treatment of colorectal cancer. World Journal Gastroenterology, 20(4), 943-956. doi: 10.3748/wjg.v20.i4.943.

7. He, D., Zhang, Y. W., Zhang, N. N., Zhou, L., Chen, J., \& Chun-kui Shao, Y. J. (2015). Aberrant gene promoter methylation of p16, FHIT, CRBP1, WWOX, and DLC1 in Epstein-Barr virus-associated gastric carcinomas. Medical Oncology, 32(4), 92. doi: $10.1007 / \mathrm{s} 12032-015-0525-\mathrm{y}$.

8. Malcolm, R.A. (2007). The Cancer Handbook (2nd ed.). Wiley-Blackwell.

9. Serra, O., Galán, M., Ginesta, M. M., Calvo, M., Sala, N., \& Salazar, R. (2019). Comparison and applicability of molecular classifications for gastric cancer. Cancer Treatment Reviews, 77: 29-34. doi: 10.1016/j.ctrv.2019.05.005.

10. Sheffield, B. S., Garratt, J., Kalloger, S. E., Torlakovic, E. E., Gilks, C. B., \& Schaeffer, D. F. (2014). Her2/neu testing in gastric cancer by immunohistochemistry: assessment of interlaboratory variation. Archives of Pathology and Laboratory Medicine 138(11), 1495-1502. doi: 10.5858/arpa.2013-0604-OA.

11. Vollan, H. K. M., \& Caldas, C. (2011). The Breast Cancer Genome - A Key for Better Oncology. BMC Cancer, 11, 501. doi: 10.1186/1471-2407-11-501.

12. Waddington, C. H. (1957). The strategy of the genes: A discussion of some aspects of theoretical biology. Retrieved from https://archive.org/details/in.ernet.dli. 2015.547782/page/n37/mode/2up.

\section{Феномен Конрада Уоддингона в разработке клинически значимой молекулярной классификации рака желудка \\ С.И. Киркилевский ${ }^{1}$ Ю.В. Думанскийㄹ, О.В. Лукьянчук, А.А. Машуков ${ }^{3,4}$, О.Н. Сулаева ${ }^{5}$, А.Г. Лурин ${ }^{3}$, А.И. Ткаченко, О.М. Згура ${ }^{4}$, О.А. Биленко ${ }^{3,4}$, В.Е. Максимовский \\ Д.В. Рациборский}

1 Онкологическая клиника "Target», Киев 2Институт экспериментальной патологии, онкологии и радиобиологии им. Р.Е. Кавецкого НАН Украины, Киев, ${ }^{3}$ Одесский национальный медицинский университет КНП «Одесский областной онкологический диспансер» Одесского областного совета ${ }^{5}$ Медицинская лаборатория CSD, Киев

Резюме. Цель исследования. Изучить влияние гистологического и молекулярного фенотипа опухолей желудка на выживаемость больных, пролеченных по стандартным протоколам. Объект и методы исследования. В этой работе представлены результаты клинического исследования, проведенного на базе научно-исследовательского отделения опухолей органов грудной полости Национального института рака и абдоминального онкохирургического отделения Коммунального некоммерческого предприятия «Одесский областной онкологический диспансер» Одесского областного совета при участии 221 больного, прооперированного по поводу рака желудка (РЖ) в период 2007-2013 гг. Средний возраст составил $60,88 \pm 10,5$ года, мужчин было 180 , женщин -41 . Всего 


\section{Оригінальні статті / Original Articles}

выполнено 143 гастрэктомии и 78 дистальных субтотальных резекции. Результаты. Все больные, включенные в исследование, были радикально прооперированы. Изъятые во время операции опухоли исследовали с использованием гистологического, иммуногистохимического методов и генетических тестов. С точки зрения хирурга, онколога и клинициста отслежены полученные результаты о наличии/отсутствии клинических параллелей и математических корреляций между маркерами. Сделан вывод об эффективности сочетания некоторых комбинаций иммуногистохимических маркеров для отделения групп больных с различной биологией РШ. Проанализированы выживаемость групп пациентов на основании анализа молекулярных маркеров VEGFR, p53, Her2, Ki-67 и рутинных гистологических маркеров (стадия, степень дифференцировки и др.). В качестве арбитра эффективности новой классификации выступает анализ выживаемости больных РЖ. Выводы. Выполнение более расширенных операций, в том числе D2-лимфодиссекций, было более эффективным при микросателитном-нестабильном и Эпштейн - Барр вирус-ассоциированном РЖ.

Ключевые слова: рак желудка; онкобелки; иммуногистохимическое исследование; новая классификация.

\section{Conrad Hal Waddington phenomenon and a novel molecular classification of gastric cancer}

S.I. Kirkilevskyi ${ }^{1}$, Yu.V. Dumanskyi ${ }^{2}$, O.V. Lukyanchuk ${ }^{3}$,

A.O. Mashukov ${ }^{3,4}$, O.M. Sulaeva ${ }^{5}$, A.G. Lurin ${ }^{3}$, O.I. Tkachenko ${ }^{4}$,

O.M. Zgura , O.A. Bilenko ${ }^{3,4}$, V.E. Maksymovskyi ${ }^{4}$, D.V. Ratsiborskyi ${ }^{3}$

${ }^{1}$ Target Cancer Clinic, Kyiv

${ }^{2}$ R.E. Kavetsky Institute of Experimental Pathology, Oncology and Radiobiology, National Academy of Sciences of Ukraine, Kyiv ${ }^{3}$ Odessa National Medical University ${ }^{4} \mathrm{CNI}$ "Odesa Regional Oncology Center" of the Odesa Regional Council ${ }^{5}$ Pathomorphological laboratory CSD, Kyiv

Resume. The aim of the study: to study the influence of malignant cell biology on the survival rate of gastric cancer patients treated by standard protocols. Object and methods of research. This paper presents the results of a clinical study been conducted on the basis of the research department of thoracic tumors of the National Cancer Institute and abdominal oncology surgery department of the Odessa Regional Oncology Dispensary of the Odessa Regional Council in 221 patients operated on for gastric cancer. 2007-2013. The average patient's age was $60.88 \pm 10.5$ years, men -180 , women -41.143 total resections and 78 distal subtotal gastrectomies have been performed. Results. All patients included in the study have been radically operated. Tumors removed during surgery have been examined deploying histological, cytological, immunohistochemical methods and some genetic tests. From the point of view of researcher, received results concerning presence/absence of clinical parallels and mathematical correlations between markers are detected, analysed and discussed. It is concluded that some combinations of immunohistochemical (IHC) markers are effective in separating groups of patients with different tumor biology pattern. Survival scenario of patients was analyzed on the basis of analysis of different molecular models, including VEGFR, p53, Her2, Ki-67 combinations and routine histological markers (stage, degree of differentiation, etc.). The analysis of the survival of patients with stomach cancer have been introduced as an arbiter of the effectiveness of novel classification. Conclusions. Performing more advanced modality of surgical operations, including D2 lymph dissection, tends to be more effective option in the cases of microsatellite-unstable and Epstein - Barr virus-associated stomach cancer models.

Key words: gastric cancer; oncoproteins; immunohistochemical examination; new classification; Conrad Hal Waddington phenomenon; D2 lymph dissection.

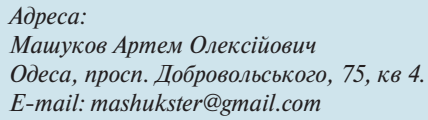

